Journal of Extension Education

Vol. 29 No. 1, 2017

DOI:https: / / doi.org/10.26725/JEE.2017.1.29.5811-5817

\title{
Farmers' Preferences for Mobile Agro Advisory Services
}

\author{
D. Prabha ${ }^{1}$ and R. Arunachalam ${ }^{2}$
}

\begin{abstract}
This study was conducted in Coimbatore district of Tamil Nadu to understand the service preferences of the mobile agro advisory services offered by the public extension system. The agro advisories offered by the e-extension centre of Tamil Nadu Agricultural University were selected for the study. A sample of 200 respondents was selected employing proportionate random sampling method. The study was carried out in terms of dimensions viz., technical components, message frequency and timings, message physical dimension, message channel and message follow up. Results of the survey showed that among the technical components majority of the respondents opined that the information on advance warning of weather risks was very much adequate, the messages on plant protection were relevant and that the messages on advance warning of weather risks were timely. With reference to the message frequency, a majority preferred frequency of the messages on daily basis and preferred to receive messages during mornings.
\end{abstract}

Keywords : Agro-advisory service; mobile phone; preferences; Tamil Nadu

\section{INTRODUCTION}

Mobile phone is a key component of agricultural development of farmers to improve the production and productivity of the cultivation. All over India, Agricultural Universities, Krishi Vigyan Kendras, private sector and Non Government Organizations send agricultural information to farmers through short message services (SMS) and voice calls. Messages covering agricultural inputs such as seed, fertilizer and cultivation techniques, plant protection, harvesting, weather forecasting and other location

based information are sent to farmers. A national survey of farmers had found that only 40 per cent of farmer households accessed information about modern agricultural techniques and inputs (NSSO, 2005). In overall Information and Communication Technologies (ICT) usage and applications, the mobile phone has been regarded as a more accessible and less expensive means to bridge the digital divide (Wade, 2004).

With regard to the usage of mobile phone networking in agricultural

1. Ph.D. Scholar and 2. Professor, Dept. of Agricultural Extension and Rural Sociology, Tamil Nadu Agricultural University, Coimbatore-3 
development, Tamil Nadu has huge number of farmers subscribed to the mobile agro advisory services from public, private and NGOs sectors. Among the public sector mobile agro service providers viz., Tamil Nadu Agricultural University (TNAU) and State Department of Agriculture are providing SMS advisories to farmers in Tamil Nadu. Among these, TNAU is the prominent technology provider and its subscribers density, geo graphical coverage and technology coverage are comparatively higher and hence SMS based agro advisories of TNAU was selected for the present study. The e-Extension centre of Tamil Nadu Agricultural University facilitates the SMS agro advisory services in Tamil Nadu. The main objective of the present study is to understand the farmers' preferences of mobile agro advisory services in Tamil Nadu.

\section{METHODOLOGY}

The study was conducted in Coimbatore district of Tamil Nadu considering the vast subscription by farmers in the district. Annur and Kinathukadavu blocks of Coimbatore district were selected for the study considering the coverage of subscribers the of the service. The study sample comprised 200 farmers (Annur - 107, Kinathukadavu - 93). The respondents from each blockwere selected byemploying proportionate random sampling method. An ex post facto research design was used and structured questionnaire was prepared and administered to collect data, by face to face interaction. Data were coded and tabulated. The statistical software SPSS was used to analyze the data.

Service preference was assessed in the terms of technical components, message frequency and timings, message physical dimension, message channel and message follow up.

\section{FINDINGS AND DISCUSSION}

\section{Technical components}

Under technical components, respondents' preferences were assessed with the response categories such as 'adequacy (adequate or inadequate)', 'relevancy (relevant or not relevant)', and 'timeliness (timely or untimely)'.

\section{Message Adequacy}

It is apparent from Table 1 that majority $(74.00 \%)$ of the respondents expressed that the technical input on advance warning of weather risks was adequate, followed by crop disease $(71.00 \%)$, price of raw materials $(68.00$ $\%)$, fertilizers application (67.50\%), and pesticide related information $\mathbf{( 5 4 . 0 0}$ $\%)$.With regard to the inadequate services, 100 per cent of the respondents had expressed that the information on cold storage networks and transportation were inadequate, followed by 98.50 per cent stated that the information input related with the export price, new crop varieties $(93.50 \%)$, seeds (89.00\%), local price $(81.00 \%)$ and cultivation techniques $(62.50 \%)$ were felt inadequate. 


\section{Message Relevancy}

It could be inferred from the findings that majority of the respondents expressed that they received relevant messages on crop disease (86.50\%), advance warning of weather risks (82.00\%), fertilizers application (81.50\%), pesticides (77.50 $\%)$ and cultivation techniques (68.00\%).

Table 1.

Service Preferences of the Respondents

$(n=200)$

\begin{tabular}{|c|c|c|c|c|c|c|c|c|c|c|c|c|c|}
\hline \multirow{3}{*}{$\begin{array}{l}\text { S1. } \\
\text { No. }\end{array}$} & \multirow{3}{*}{ Particulars } & \multicolumn{4}{|c|}{ Adequacy* } & \multicolumn{4}{|c|}{ Relevancy* } & \multicolumn{4}{|c|}{ Timeliness* } \\
\hline & & \multicolumn{2}{|c|}{ Adequate } & \multicolumn{2}{|c|}{ Inadequate } & \multicolumn{2}{|c|}{ Relevant } & \multicolumn{2}{|c|}{$\begin{array}{c}\text { Not } \\
\text { relevant }\end{array}$} & \multicolumn{2}{|c|}{ Timely } & \multicolumn{2}{|c|}{ Untimely } \\
\hline & & No. & $\%$ & No. & $\%$ & No. & $\%$ & No. & $\%$ & No. & $\%$ & No. & $\%$ \\
\hline A) & Technical Co & mpo & nents & & & & & & & & & & \\
\hline 1. & $\begin{array}{l}\text { Cultivation } \\
\text { techniques }\end{array}$ & 75 & 37.50 & 125 & 62.50 & 136 & 68.00 & 64 & 32.00 & 172 & 86.00 & 28 & 14.00 \\
\hline 2. & $\begin{array}{l}\text { New crop } \\
\text { varieties }\end{array}$ & 13 & 6.50 & 187 & 93.50 & 43 & 21.50 & 157 & 78.50 & 67 & 33.50 & 133 & 66.50 \\
\hline 3. & Crop disease & 142 & 71.00 & 58 & 29.00 & 173 & 86.50 & 27 & 13.50 & 189 & 94.50 & 11 & 5.50 \\
\hline 4. & Seeds & 22 & 11.00 & 178 & 89.00 & 57 & 28.50 & 143 & 71.50 & 73 & 36.50 & 127 & 63.50 \\
\hline 5. & $\begin{array}{l}\text { Fertilizers } \\
\text { application }\end{array}$ & 135 & 67.50 & 65 & 32.50 & 163 & 81.50 & 37 & 18.50 & 185 & 92.50 & 15 & 7.50 \\
\hline 6. & Pesticides & 108 & 54.00 & 92 & 46.00 & 155 & 77.50 & 45 & 22.50 & 181 & 90.50 & 19 & 9.50 \\
\hline 7. & $\begin{array}{l}\text { Advance } \\
\text { warning of } \\
\text { weather risks }\end{array}$ & 148 & 74.00 & 52 & 26.00 & 164 & 82.00 & 36 & 18.00 & 191 & 95.5 & 9 & 4.50 \\
\hline 8. & $\begin{array}{l}\text { Cold storage } \\
\text { networks }\end{array}$ & - & - & 200 & 100.00 & - & - & 200 & 100.00 & - & - & 200 & 100.00 \\
\hline 9. & $\begin{array}{l}\text { Trans } \\
\text { portation }\end{array}$ & - & - & 200 & 100.00 & - & - & 200 & 100.00 & - & - & 200 & 100.00 \\
\hline 10. & $\begin{array}{l}\text { Price of raw } \\
\text { materials }\end{array}$ & 136 & 68.00 & 64 & 32.00 & 97 & 48.50 & 103 & 51.50 & 126 & 63.00 & 74 & 37.00 \\
\hline 11. & Local price & 38 & 19.00 & 162 & 81.00 & 94 & 47.00 & 106 & 53.00 & 129 & 64.50 & 71 & 35.50 \\
\hline 12. & Export price & 3 & 1.50 & 197 & 98.50 & 2 & 1.00 & 198 & 99.00 & 9 & 4.50 & 191 & 95.50 \\
\hline
\end{tabular}

(* multiple responses) 


\section{Message Timings}

It is observed from Table 1 that majority $(95.50 \%)$ of the respondents had expressed that they received timely messages on advance warning of weather risks, followed by crop disease.

Further, they considered the receipt of some of the messages as untimely such as those related with cold storage networks and transportation (100.00\%), export price (95.50\%), new crop varieties $(66.50 \%)$ and the seeds (63.50\%).

\section{Preferred Frequency of Messages}

It was found out that majority $(53.50 \%)$ of the respondents preferred to receive the messages on daily basis, followed by 23.50 per cent of the respondents preferred to receive the messages once in 2 days, weekly basis $(9.50 \%)$, monthly basis $(7.00 \%)$ and the rest 6.50 per cent of the respondents preferred to receive the messages occasionally receiving.

\section{Preferred Time of Receiving Messages}

It was found out that majority $(55.00$ $\%$ of the respondents preferred to receive the messages during 'morning hours', followed by 21.00 per cent of the respondents' preferred timings of the messages was during 'anytime'. The other preferences such as during 'afternoon' (12.50\%), during 'night' (7.50 \%) and during 'evening' hours $(2.50 \%)$ were also observed in this study.

\section{Preferred Length of the Messages}

The distribution of respondents according to their preferred length of the messages is presented in Table 2 .

Table 2.

Distribution of Respondents according to their Preferred length of the Messages

\begin{tabular}{|c|l|c|c|}
\hline $\begin{array}{c}\text { S1. } \\
\text { No. }\end{array}$ & $\begin{array}{c}\text { Preferred } \\
\text { frequency of } \\
\text { the messages }\end{array}$ & $\begin{array}{c}\text { Number } \\
\text { (n=200) }\end{array}$ & $\begin{array}{c}\text { Percen } \\
\text { tage }\end{array}$ \\
\hline 1. & 100 words & 7 & 3.50 \\
\hline 2. & 150 words & 19 & 9.50 \\
\hline 3. & 180 words & 13 & 6.50 \\
\hline 4. & 200 words & 4 & 2.00 \\
\hline 5. & $\begin{array}{l}\text { As per the } \\
\text { regular length } \\
\text { (50 - 100 } \\
\text { words) }\end{array}$ & 157 & 78.50 \\
\hline & \multicolumn{1}{|c|}{ Total } & $\mathbf{2 0 0}$ & $\mathbf{1 0 0 . 0 0}$ \\
\hline
\end{tabular}

It could be seen from Table 2 that a vast majority $(78.50 \%)$ of the respondents stated that the present regular length of the messages was their choice, followed by 9.50 per cent of the respondents preferred their choice of length as 150 words per message.

\section{Preference on the Language Usage}

It was found out that little less than half $(48.00 \%)$ of the respondents preferred the message strictly to be their local language, followed by 21.50 per cent of the respondents stated that the 
scientific terminologies can be included in messages. Mix up of English with local language was preferred by about one tenth of the respondents (19.00\%). The rest 11.50 per cent of the respondents stated that they are not very specific with the use of language with regard to the SMS based advisories.

\section{Form of the Messages}

The distribution of respondents according to their preferred form of the messages is presented in Table 3 .

Table 3.

Distribution of Respondents according to their Preferred form of Messages

\begin{tabular}{|c|c|c|c|}
\hline $\begin{array}{l}\text { S1. } \\
\text { No. }\end{array}$ & $\begin{array}{l}\text { Form of } \\
\text { Messages }\end{array}$ & Number* & $\begin{array}{c}\text { Percen } \\
\text { tage }\end{array}$ \\
\hline 1. & Text alone & 200 & 100.00 \\
\hline 2 . & Voice alone & 97 & 48.50 \\
\hline 3. & Video alone & 112 & 56.00 \\
\hline 4. & $\begin{array}{l}\text { Picture } \\
\text { alone }\end{array}$ & 105 & 52.50 \\
\hline 5. & $\begin{array}{l}\text { Text to be } \\
\text { supported } \\
\text { with audio }\end{array}$ & 130 & 65.00 \\
\hline 6. & $\begin{array}{l}\text { Text to be } \\
\text { supported } \\
\text { with Video }\end{array}$ & 137 & 68.50 \\
\hline 7. & $\begin{array}{l}\text { Text to be } \\
\text { supported } \\
\text { with } \\
\text { pictures }\end{array}$ & 145 & 72.50 \\
\hline
\end{tabular}

( ${ }^{*}$ multiple responses)
It is clear that 100 per cent of the respondents preferred only text based messages, followed by nearly three-fourth $(72.50 \%)$ of the respondents preferred text messages with pictures, 68.50 per cent preferred as text to be supported with video, 65.00 per cent preferred as text to be supported with audio. Fifty six per cent of the respondents preferred only video messages, followed by picture alone $(52.50 \%)$ and 48.50 per cent of the respondents preferred voice alone.

\section{Message Channel}

The distribution of respondents according to their preferred message channel is presented in Table 4.

Table 4.

Distribution of respondents according to their preferred message channel

\begin{tabular}{|c|l|c|c|}
\hline \multicolumn{5}{|c}{ S1. } \\
No. & $\begin{array}{c}\text { Preferred } \\
\text { frequency of } \\
\text { the messages }\end{array}$ & Number & $\begin{array}{c}\text { Percen } \\
\text { tage }\end{array}$ \\
\hline 1. & SMS & 200 & 100.00 \\
\hline 2. & Whatsapp & 77 & 38.50 \\
\hline 3. & Telegram app & - & 0.00 \\
\hline 4. & Viber app & - & 0.00 \\
\hline 5. & E mails & 47 & 23.50 \\
\hline 6. & $\begin{array}{l}\text { Other social } \\
\text { media tools } \\
\text { like FB / } \\
\text { Twitter / Blogs } \\
\text { / Linkedin / } \\
\text { others }\end{array}$ & 47 & 23.50 \\
\hline
\end{tabular}

(* multiple responses) 
It is revealed from Table 7 that 100 per cent of the respondents preferred to receive messages through SMS, followed by 38.50 per cent of the respondents preferred whatsapp mode and 23.50 per cent of the respondents preferred emails and social media tools like facebook as their choice of channels.

The findings reveal that 100 percentage of the respondents preferred follow-up messages.

Even though 100 percent of the respondents preferred only follow up messages, 14 respondents were also willing to receive the same messages repeatedly. Their preference on the choice of technical information was also stated. They stated that they were very much willing to receive technical messages on seed varieties, cultivation techniques, marketing, application of fertilizers, weather forecast and crop protection.

Futher, the above 14 respondents were found to differ in their preference on the frequency of message repetition such as once, twice and thrice. Here 13 per cent of the respondents stated that they were willing to receive the same message in one week interval and the remaining respondents preferred 15 days interval.

\section{CONCLUSION}

This study assessed the farmers' preferences of mobile agro advisory services in Tamil Nadu. According to the findings, messages on crop disease, fertilizer application, pesticides and advance warning of weather risks of the messages were felt as adequate, relevant and timely messages by the farmers. But messages on new crop varieties, seeds, cold storage, transportation and export price were felt as inadequate, irrelevant and untimely by the famers. Most of the farmers preferred to receive messages on daily basis and during morning hours. Farmers preferred the regular length of the messages and strict use of local language (75- 100 words). They preferred text form of messages through SMS mode. Timeliness is a factor that impacts agricultural information to a great extent. Late or too early messages do not have much utility for the farmers. In addition to text messages, picture, voice, video text to be supported with pictures and voice based services need to be initiated to make them more interactive and be in line with the changing needs of the next generation users and mobile phones. Agricultural information should be beyond the regular length of the messages to provide clarity of information for the farmers.

\section{REFERENCES}

Jayanthi, M. \& Asokhan, M. (2016) Constraints faced by M-Kisan users. Journal of Extension Education, 28(1)

NSSO.(2005). Situation assessment survey of farmers: Access to modern technology for farming. National sample survey, 59th round Report, 499 (59/33/2). New Delhi: GOI. 
Rebello, J. (2010). Indian Cell Phone Penetration to Reach 97 Percent in 2014. Retrieved from http://www. isuppli.com/ Mobile-and-WirelessCommunications/News/Pages/India-
Cell-Phone-Penetration-to-Reach-97Percent-in-2014.aspx.

Wade, R.H. (2004) Bridging the digital divide: New route to development or new form of dependency, New York: Oxford University Press. 